\title{
Effects of Integrated Use of Lime and Nitrogen Fertilizer on Yield and Yield Components of Maize (Zea mays I.) at Nitisols of Burie Area, Northwestern Ethiopia
}

\author{
Birtukan Amare Kebede ${ }^{1} \quad$ Eyayu Molla Fetene $^{2} \quad$ Yihenew Gebreselassie $^{2} \quad$ Habtamu Tadele Belay $^{3}$ \\ Tesfaye Bayu Zeleke ${ }^{3}$ \\ 1.Department of Natural Resources and Plant Science, Burie Polytechnic College, Burie, Ethiopia \\ 2.Department of Natural Resources Management, Bahir Dar University, Bahir Dar, Ethiopia \\ 3.Department of Natural Resources Management, Debre Markos University Burie Campus, Burie, Ethiopia
}

\begin{abstract}
Soil acidity coupled with soil nutrient depletion negatively affect the performance and yield of maize in the Amhara National Regional State Ethiopia. This study was carried out at Burie district in one cropping season to determine the effect of integrated use of lime and urea fertilizer rate on yield and yield components of Maize. The treatments include lime $\left(0\right.$ and $\left.0.5 \mathrm{t} \mathrm{ha}^{-1}\right)$ and nitrogen $\left(0,100,200,300\right.$, and $\left.400 \mathrm{~kg} \mathrm{ha}^{-1}\right)$. The maize variety BH-661 was used as a test crop. The experiment was laid out in a randomized complete block design (RCBD) with ten treatments replicated three times. Yield and yield components of maize were collected and analyzed. The analysis of variance result revealed that, interaction effect of lime and $\mathrm{N}$ fertilizer reduced the tassling period (88 days in the application of $0.5 \mathrm{t} \mathrm{ha}^{-1}$ lime with $100 \mathrm{~kg} \mathrm{ha}^{-1} \mathrm{~N}$ to 85 days in the application of $0.5 \mathrm{t}^{-1}$ lime with $400 \mathrm{~kg} \mathrm{ha}^{-1} \mathrm{~N}$ ) and silking period from 91 days to 88 days. Grain yield was highly and positively correlated with AGDB $(\mathrm{r}=0.996)$ and $\mathrm{HI}(\mathrm{r}=0.987)$. But GY was highly and negatively correlated with DT $(\mathrm{r}=-$ $0.957)$ and DS ( $\mathrm{r}=-0.925)$. Grain yield of maize was positively and significantly correlated with yield components. The maximum AUE (3.76\%) was recorded from T10 than T7 of $(3.16 \%)$. Based on economic analysis the optimum rate of lime and $\mathrm{N}$ fertilizer was obtained $0.5 \mathrm{t} \mathrm{ha}^{-1}$ lime and $300 \mathrm{~kg} \mathrm{ha}^{-1}$ nitrogen fertilizer. So, combined application of $0.5 \mathrm{t} \mathrm{ha}^{-1}$ lime and $300 \mathrm{~kg} \mathrm{ha}^{-1}$ Nitrogen is economically reasonable and recommended to the farmers.
\end{abstract}

Keywords: Integrated, Liming, yield, Optimum, Soil acidity

DOI: $10.7176 /$ ALST/88-03

Publication date:July $31^{\text {st }} 2021$

\section{Introduction}

Maize (Zea mays L.) is a member of Gramineae family, and it was originated in America and first cultivated in the area of Mexico more than 7,000 years ago [1]. In world production, maize is ranked as the third major cereal crop after wheat and rice [2]. It is one of the most important food crops worldwide. It has the highest average yield per hectare and it is grown in most parts of the world over a wide range of environmental conditions [3]. Ethiopia is the fifth largest producer of maize in Africa and smallholder farmers make up 94\% of the crop production [4].

Maize is cultivated in a wide range of altitudes, moisture regimes, soil types, and terrains, mainly by smallholder crop producers. It is mainly produced in southern, western, central, and eastern regions of Ethiopia [5]. But specifically, the mid-altitude, sub-humid agro-ecology (1,000-1,800 m.a.s.l) is the most important maize producing environment in Ethiopia [6]. The popularity of maize in Ethiopia is partly because of its high value as a food crop as well as the growing demand for the straw as animal fodder and source of fuel for rural families [7]. Maize is used as human food (accounting for $62 \%$ of all household cereal consumption), as a source of cash income (accounting for about 54\% of cash income), as fuel (about 25\%), feed for livestock and industrial purposes [8]. Farmers consume maize by preparing different dishes, including bread, injera, thick porridge, boiled maize, roasted maize and local beer. Green cobs are also sold in big cities and towns [8]. The smallholder farmers' of Ethiopia owning $97 \%$ of the total maize land contribute $95 \%$ of the national maize production [10]. On the other hand, commercial farms owning only 3\% of land contribute $5 \%$ of the total production. In the Amhara region, maize production accounts $519,495.71 \mathrm{ha}^{-1}$ with productivity of $3.78 \mathrm{tha}^{-1}$, while in west Gojjam it accounts $212,556.78 \mathrm{ha}^{-1}$ with a productivity of $4.23 \mathrm{tha}^{-1}[10]$.

Nitrogen is a key factor in achieving optimum grain yield. On the other hand, grain yield is the main target of crop production. Grain yield of maize is a product of three yields components, i.e. the number of ears per unit area, the number of grains per ear and the unit grain weight [11]Increase or decrease in any one of these components, keeping the size of other components constant, contributes to increase or decrease in grain yield, respectively, and thus any exercise whether agronomic (management) or breeding type (genotype), which increase any of these components, keeping the other components constant, will increase the final grain yield. [12] reported that ears plant ${ }^{-1}$, ear length, number of kernels ear ${ }^{-1}$ and 1000 kernel weight directly influence the grain 
yield and indirectly affect several other parameters. Any kind of stress, for example a drought stress, during or around the stage at which these components are formed may severely affect grain yield. According to [13] grain yield was increased over control per $\mathrm{kg} \mathrm{N}$ applied and time of $\mathrm{N}$ application in maize has been due to good synchrony if $\mathrm{N}$ is applied nearest to the time it is needed by the crop. Nitrogen fertilizer use has played a significant role in increase of crop yield. Yield reduction in maize due to $\mathrm{N}$ deficiency is more than of other elements deficiency [14]. Although maize is usually considered as energy food, it contains important quantity of protein. The percentage of $\mathrm{N}$ in maize actually varies according to the supply of nitrogen to the crop (fertilizer plus soil), genetic characteristics of the hybrids, planting rate and weather conditions [15].Nitrogen fertilizer application is required to optimize maize grain yields and tends to improve physical grain quality in maize by increasing kernel weight and protein concentration [15]. According to [16] higher nitrogenous fertilizer delays the senescence of leaves and increased succulence of plants therefore; physiological maturity was increased with increment in nitrogen level. Likewise, successive increment in nitrogen rate from 0 to $200 \mathrm{~kg} \mathrm{~N} \mathrm{ha}^{-1}$ significantly increased maize grain yield [17]. The low productivity of maize is mainly attributed to many factors including frequent occurrence of drought, declining soil fertility [18], poor agronomic practice, and limited use of inputs, poor seed quality, disease, and pests [19]. Among these, declining soil fertility (due to continuous cultivation with low input) is a major limitation to crop production and productivity in smallholder farms in Ethiopia [20].

Agricultural liming material is the most common soil management practices whose addition to agricultural soil in moderate amounts may be beneficial as plant nutrients, minimize soil acidification [21]. The beneficial effects of liming soil are neutralization of exchangeable $\mathrm{Al}$, increase $\mathrm{Ca}, \mathrm{Mg}, \mathrm{P}$ and $\mathrm{Mo}$, availability, stimulate microbiological activity in the soil, and improve the physical structure of soil [22]. Although, the Amhara National Regional State (ANRS) especially Burie district is a potential area for maize production, the productivity is generally low, which is attributed to several factors from thus factor soil erosion which cause leaching of basic cations leads to soil acidity and poor soil nutrient managements are mentioned. Thus, identifying effective use of Integrated Nutrient Management (INM) ways is needed to replenish the soil nutrients and increase grain yield of maize in the study area. Therefore, the objective of the present study was to determine the effects of integrated use of lime and nitrogen fertilizers on maize yield and yield components on the Nitisols of Burie area, Northwestern Ethiopia.

\section{Materials and methods}

\subsection{Research site location and soil}

The experiment was conducted in Burie district, West Gojjam Zone of Amhara National Regional State (ANRS) during the 2018/2019 main cropping season. The study site is located between latitude of $10^{\circ} 43^{\prime} 0^{\prime \prime}$ to $10^{\circ} 47^{\prime} 0^{\prime \prime}$ North and longitude of $37^{\circ} 3^{\prime} 0^{\prime \prime}$ to $37^{\circ} 6^{\prime} 0^{\prime \prime}$ East. It is located in the northwestern part of Ethiopia at a distance of $411 \mathrm{~km}$ from Addis Ababa and $148 \mathrm{~km}$ southwest of Bahir Dar city. The altitude of the Burie district ranges from 2087 to 2,637 m.a.s.l. The soil of the area is characteristically humic Nitisols (BWAO, 2019). In general, soils of the area are well-drained, clay in texture, and strongly acidic Nitisols in soil reaction (BWAO, 2019). The district has a total of 29,629 ha agricultural land from this $42.8 \%$ is covered by maize crop in the 2018/2019 crop production year (BWAO, 2019). The mean yield of maize from all varieties was 5.55 tha $^{-1}$ which is low as compared with the production potential of the area. The experimental site was covered by wheat crop during the past cropping seasons. The recommended $\mathrm{N}$ and NPS fertilizers in the study area are $200 \mathrm{~kg} \mathrm{ha}^{-1} \mathrm{~N}$ and $200 \mathrm{~kg}$ $\mathrm{ha}^{-1}$ NPS, respectively (BWAO, 2019). According to the Amhara Meteorological Agency report (2020), the mean annual rainfall of the District was $1375.8 \mathrm{~mm}$ and the mean minimum, mean maximum and average air temperature of ten years (2010-2019) data in the study area was $12.31{ }^{\circ} \mathrm{C}, 25.93^{\circ} \mathrm{C}$, and $19.12^{\circ} \mathrm{C}$ (Fig.1). Summary of 10 years (2010-2019) mean annual rainfall and temperature data of study area is presented. 


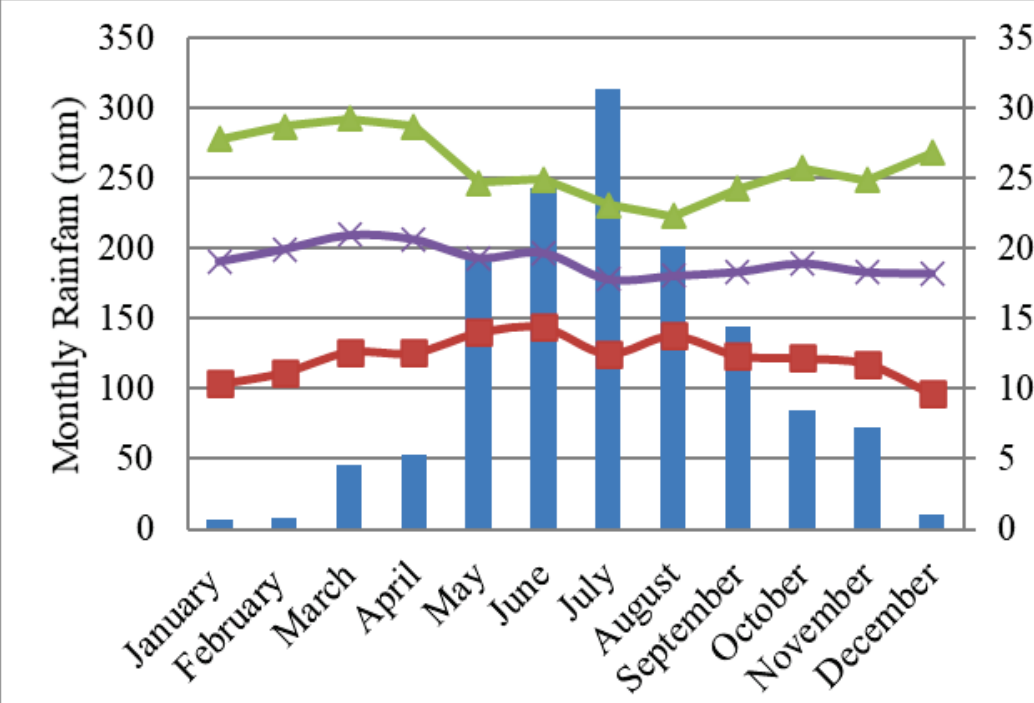

Mean Rainfall 30

- Maximum Temperature

Months

Fig1: Monthly rainfall $(\mathrm{mm})$, minimum, maximum and average air temperature $\left({ }^{0} \mathrm{C}\right)$ of the study area during 2010-2019

\subsection{Experimental Materials used Plant, fertilizer and lime}

The maize variety H-661 (Bako Hybrid-661) which is adapted to the agro-ecology and registered at the national level was collected from Amhara Seed Enterprise and used as a test crop.

As a feretilizer urea $(46 \% \mathrm{~N})$ was applied at five different rates $\left(0,100,200,300\right.$, and $\left.400 \mathrm{~kg} \mathrm{ha}^{-1}\right)$ and was applied in one dose at knee height sage. This fertilizer was applied by banding at a distance 2 to $3 \mathrm{~cm}$ away from the plant and at $20 \mathrm{~cm}$ depth and covered immediately with soil. The recommended rate of NPS (19\% N, 38\% $\mathrm{P}_{2} \mathrm{O}_{5}$, and $7 \% \mathrm{~S}$ ) fertilizer was uniformly applied to all plots at the time of planting.

Liming material in the form of calcium carbonate $\left(\mathrm{CaCO}_{3}\right)$ passed a 100-mesh was applied. According to Burie district Agricultural Office Manual (2019), there are two ways of lime application. First, during seed sowing (i.e row application) if the lime is a powder, and the secondis broadcasting application for granular type of lime. First, during seed sowing one fourth $\left(20 \mathrm{tha}^{-1}\right)$ of the recommended rate of broadcasting (i.e $0.5 \mathrm{t} \mathrm{ha}^{-1}$ lime) was applied. Broadcasting application is recommended to apply one or two months before seed sowing (BWAO, 2019). Lime was added as the district agricultural office manual, based on the soil $\mathrm{pH}$ of the experimental site. According to BWAO (2019) unpublished mannual, if the $\mathrm{pH}\left(\mathrm{H}_{2} \mathrm{O}\right)$ value of the soil is between 5.14 to 5.32, the recommended lime rate for broadcasting application method was $20 \mathrm{t} \mathrm{ha}^{-1}$. For row application method, $0.5 \mathrm{t} \mathrm{ha}^{-1}$ of the recommended rate for broadcasting method was used (BWAO, 2019). Since the soil $\mathrm{pH}$ of experimental site was 5.20, the amount of lime rate added during maize sowing was $0.5 \mathrm{t} \mathrm{ha}^{-1}$.

\subsection{Treatments and experimental design.}

This experiment was laid out as a randomized complete block design (RCBD) with three replications and ten treatments. A total of 30 experimental plots were designed. Two factors was involved in the study, namely five levels of $\mathrm{N}\left(0,100,200,300\right.$ and $400 \mathrm{~kg} \mathrm{ha}^{-1}$ Nitrogen $)$ and two level of lime $\left(0\right.$ and $\left.0.5 \mathrm{t} \mathrm{ha}^{-1}\right)$ to have a total of ten $(10)$ treatments that were arranged in $5^{*} 2$ factorial combinations replicated 3 times.

\section{Application of treatments and field management}

The field was leveled and divided into three blocks which were lastly divided into 30 plots. The plots were leveled and ridges were prepared manually. Each gross plot had an area of $3.75 \mathrm{~m} \times 3.5 \mathrm{~m}\left(13.125 \mathrm{~m}^{2}\right)$ and consists of 5 rows of $3.5 \mathrm{~m}$ length. The spacing between rows and between plants was $0.75 \mathrm{~m}$ and $0.25 \mathrm{~m}$, respectively and the spacing between plots and blocks was $0.5 \mathrm{~m}$ and $1 \mathrm{~m}$ respectively. The treatments were a ssigned to each plot randomly.

\subsection{Experimental Procedure}

\section{Fertilizer application and field activities}

The experimental plot was plowing by tractor and oxen. Accordingly, the field was plowed three times, the first plowing, was done in the first of April with disck plough. The second \& final plowing was conducted by oxen 
driven local plow "Maresha" at first and last May and seeding or sowing was conducted as per the spacing of the treatment. The experimental field was hand weeded twice at 25 and 45 days after planting to control weeds. A late emerging weed was removed by hoeing to avoid interference with the maize plants for the $\mathrm{N}$ applied from NPS source. All other agronomic practices such as fertilization, hoeing, disease, insects and weeds management was as per the recommendation. Finally, maize plants in the central net plot area were harvested.

\section{Collected data for yield and yield components of Maize}

The following phonological, yield and yield components of maize data were collected.

Days to $\mathbf{5 0 \%}$ tasseling was recorded when more than 50 percent of the plants produced tassels in each plot. Days to $\mathbf{5 0 \%}$ silking was recorded when more than 50 percent of the plants produced silks in each plot.

Days to $\mathbf{9 0 \%}$ maturity was recorded as the number of days from emergence to the date on which about 90 percent of the plants in a plot matured (ninety percent plants showed drying of cobs husk).

Plant height $(\mathrm{cm})$ : five plants were selected randomly from each net plot. Plant height was measured as the distance from the base of the plant to the height of the first tassel branch and average height was calculated. Number of leaves per plant: Five plants were randomly selected from three central row of each net plot and counted and their average was worked out.

Number of cob per plant: Five plants were selected randomly and the total numbers of cobs were divided by the total number of plants harvested.

Number of grains per cob: five cobs in each net plot were randomly selected, and then number of grains in each cob were counted and averaged.

Thousands grain weight (g): Two samples of thousand grains had taken at random from each treatment then weighed by digital balance and average was recorded. The 1000 grain weights was weighed after testing seed moisture content by using seed moisture tester instrument at Ethiopia commodity exchange (ECX) office, Burie branch. The final dry weight of 1000 grains was computed using $12.5 \%$ as market standard seed moisture content of maize.

Grain yield (kg ha $\left.{ }^{-1}\right)$ : After sun drying, the cobs were threshed manually and yield was recorded on per plot basis, with moisture content $12.5 \%$, and then converted into $\mathrm{kg} \mathrm{ha}^{-1}$.

Above ground dry biomass yield $\left(\mathrm{kg} \mathrm{ha}^{-1}\right)$ : Plants from the net plot area were harvested at physiological maturity and weighed after sun drying.

Harvest index: was computed as the ratio of grain yield (GY) to the total above ground Dry-mass (DM) yield. Straw yield: was determined by subtracting grain yield from above ground dry biomass.

\subsection{Data analysis}

The collected data were computed by analysis of variance (ANOVA) using SAS statistical package program version 9.0 (SAS, 2004). All significant treatment means were compared using the least significant difference (LSD) test at 5\% probability level. Pearson correlation analysis was used to determine the relationship between yield and yield components of maize.

\section{Economic analysis}

The mean grain data was adjusted down by $90 \%$ (to reduce the grain gap between experimental plots and farmers field) partial budget analysis was performed following the CIMMYT partial budget methodology [24]. The gross benefit was calculated as grain yield $\left(\mathrm{kg} \mathrm{ha}^{-1}\right)$ multiplied by field price that farmers receive for the sale of the crop. Total variable cost is the sum of cost that has variable or specific to a treatment against the control. Net benefit was calculated by subtracting total variable cost from the gross benefit. Analysis of marginal rate of return (MRR) was carried out for non- dominated treatments, and MRR were compared to a minimum acceptable rate of return (MARR) of $100 \%$ in order to select the optimum treatments to recommend for farmers. A treatment having acceptable MRR and highest NB is said to be economically profitable and will be recommended for farmers [24]. Marginal rate of return was calculated using the procedures described by [24] as Eq. (1):

$$
\text { Marginal rate of return }(M R R)=\left(\frac{\text { change in net benefit }}{\text { change in total variable cost }}\right) * 100
$$

\section{Agronomic use efficiency}

The NPS, nitrogen and lime fertilizer agronomic efficiency was calculated using the procedure described by [25] as Eq. (2):

$$
A E\left(\frac{K g}{k g}\right)=\frac{G f(k g)-G u(k g)}{N a(k g)},
$$

where; AE stands for agronomic efficiency, Gf and $\mathrm{Gu}$ for grain yield in fertilized and unfertilized plots, respectively, and Na for quantity of lime, urea and NPS fertilizer applied. 


\section{Results and Discussion}

\subsection{Effects of Nitrogen fertilizer and lime on moropho-phenological parameters}

Integrated use of lime and $\mathrm{N}$ fertilizer significantly $(\mathrm{P} \leq 0.05)$ affected days to $50 \%$ tasselling of maize while significantly $(\mathrm{P} \leq 0.01)$ affected days to $50 \%$ silking (Table 1$)$. Similar to days to tasselling, days to silking were delayed with $\mathrm{N}$ deficiency. Nitrogen fertilizer and lime interaction had highly significantly $(\mathrm{P} \leq 0.01)$ affected days to $90 \%$ maturity. This indicates that increasing the $\mathrm{N}$ rate significantly increased the number of days to physiological maturity.

\section{Tasselling period}

The maximum and minimum tasselling period was 88 days from plots treated with $0.5 \mathrm{tha}^{-1}$ lime and $100 \mathrm{~kg} \mathrm{ha}^{-1}$ $\mathrm{N}$ (i.e treatment T7), and 85 days was recorded in $0.5 \mathrm{t} \mathrm{ha}^{-1}$ lime and $400 \mathrm{~kg} \mathrm{ha}^{-1} \mathrm{~N}$ (i.e treatment T10) (Table 1). This might be due the uptake of most of the $\mathrm{Ca}$ and $\mathrm{N}$ by plants that come from lime and $\mathrm{N}$, respectively. According to [26] who reported the significant $(\mathrm{P} \leq 0.01)$ influence of the interaction of lime and potassium on the number of days required for $50 \%$ flowering on the soybean crop on acidic soil in Gobu Sayo district, western Ethiopia. [23] found synergistic effect of applied lime and inorganic plant nutrient sources and highly influenced phonological parameters of Barely on acid soils of Wolmera district, West Showa, and Ethiopia. The tasseling period slowed as the nitrogen level decreased and the maximum days to $50 \%$ tasseling was 91 days that was recorded under $0 \mathrm{~kg} \mathrm{~N} \mathrm{ha}^{-1}$. The fastest $50 \%$ tasseling was 85 days recorded in the plot treated with $400 \mathrm{~kg} \mathrm{~N}^{-1}$ (Table 1 and Figure 2). This might be due to the uptake of more $\mathrm{N}$ by the maize plant for growth as tasseling time is affected by the amount of $\mathrm{N}$ in the soil. Thus, with an increase in $\mathrm{N}$ the availability of nutrients in the soil increased. This condition might lead to uniform flowering. Likewise [27] reported a decrease in days of 50\% tasseling from 82.44 to 80.89 days in the maize crop when the $\mathrm{N}$ rate was increased from 0 to $115 \mathrm{~kg} \mathrm{ha}^{-1}$. Similarly, [27] reported the earlier days to tasseling in the maize crop treated with increased rates of N. The delaying of flowering date in response to $\mathrm{N}$ deficiency has been previously acknowledged by different researchers [28], [29]. However, the result of this study disagreed to [30] that reported a consistent increase in days to $50 \%$ tasselling due to the prolonging vegetative growth period, when the rate of nitrogen applied increased.

\section{Days of sillking}

As shown in Table 1 the maximum (91 days) and minimum (88 days) DS was recorded in plots treated with 0.5 $\mathrm{t} \mathrm{ha} \mathrm{h}^{-1}$ lime and $100 \mathrm{~kg} \mathrm{ha}^{-1} \mathrm{~N}$ as compared with control DS (94 days). This is in line with [31] showed the significant influence of fertility management on days to silking on maize crop in central plain zone of Uttar Pradesh, India and Ethiopia respectively.[32] also recorded delayed (68 days) of silking was after the application of cattle manure $\left(5 \mathrm{t} \mathrm{ha}^{-1}\right)$ with phosphorus $\left(160 \mathrm{~kg} \mathrm{P} \mathrm{ha}^{-1}\right)$ and with or without PSB. The analysis showed that, days to $90 \%$ maturity was affected by the interaction effect of lime and $\mathrm{N}$. The shortest (144) days to maturity was recorded from the control and the longest (149) days to $90 \%$ maturity was recorded from plots treated with $0.5 \mathrm{t} \mathrm{ha}^{-1}$ lime and $400 \mathrm{~kg} \mathrm{ha}^{-1} \mathrm{~N}$. This is due to the availability of $\mathrm{N}$ in the soil from urea fertilizer. This might be due to enhancing shoot growth, leave to be green, and maximizes the number of days required to be matured. This might be because of increasing $\mathrm{N}$ from urea and $\mathrm{Ca}^{2+}$ from lime enhances days to maturity [33]. As the rate of $\mathrm{N}$ fertilizer and lime increased days to $90 \%$ maturity was increased. [34] reported maximum maturity by combining compost and mineral fertilizer. [35] reported that physiological maturity was significantly extended by applications of lime, vermicomposting and chemical P fertilizer on the maize crop in Ebantu district, Western highlands of Ethiopia. 
Table 1. Mean moropho-phenological parameters as influenced by the interaction effect of lime and Nitrogen fertilizer

\begin{tabular}{|c|c|c|c|c|c|}
\hline \multicolumn{3}{|c|}{ Interaction effect } & \multicolumn{3}{|c|}{ Growth parameters } \\
\hline Lime & Nitrogen fertilizer rate & Treatments & DT(day) & DS (day) & DM (day) \\
\hline \multirow{5}{*}{ L0 } & N0 & $\mathrm{T} 1$ & $92.33^{a}$ & $96.33^{\mathrm{a}}$ & $143.67^{\mathrm{e}}$ \\
\hline & N1 & $\mathrm{T} 2$ & $89^{c}$ & $95^{\mathrm{b}}$ & $146^{\mathrm{d}}$ \\
\hline & $\mathrm{N} 2$ & $\mathrm{~T} 3$ & $88^{\mathrm{d}}$ & $92^{\mathrm{d}}$ & $146^{\mathrm{d}}$ \\
\hline & N3 & $\mathrm{T} 4$ & $87^{\mathrm{e}}$ & $91^{\mathrm{e}}$ & $147.66^{\mathrm{b}}$ \\
\hline & N4 & T5 & $86.33^{\mathrm{ef}}$ & $90^{\mathrm{f}}$ & $147.67^{\mathrm{b}}$ \\
\hline \multirow[t]{5}{*}{$\mathbf{L 1}$} & N0 & T6 & $90^{\mathrm{b}}$ & $94^{\mathrm{c}}$ & $142.33^{f}$ \\
\hline & N1 & $\mathrm{T} 7$ & $88^{\mathrm{d}}$ & $91^{\mathrm{e}}$ & $146.66^{\mathrm{cd}}$ \\
\hline & $\mathrm{N} 2$ & $\mathrm{~T} 8$ & $87^{\mathrm{e}}$ & $90^{f}$ & $147^{\mathrm{cb}}$ \\
\hline & N3 & T9 & $85.66^{\mathrm{fg}}$ & $88.33^{\mathrm{g}}$ & $147.66^{\mathrm{b}}$ \\
\hline & N4 & $\mathrm{T} 10$ & $85^{\mathrm{g}}$ & $88^{\mathrm{g}}$ & $149^{\mathrm{a}}$ \\
\hline Mean & & & 87.83 & 91.56 & 146.36 \\
\hline LSD & & & 0.7157 & 0.68 & 0.95 \\
\hline$S E \pm$ & & & 0.21 & 0.252 & 0.333 \\
\hline $\mathbf{C V}$ & & & 0.475 & 0.43 & 0.37 \\
\hline
\end{tabular}

$\mathrm{DT}=$ days to $50 \%$ tassling, $\mathrm{DS}=$ days to $50 \%$ silking, DM=days to $90 \%$ maturity, days to followed by the same letters in a column are not statically different at $p<0.05$.

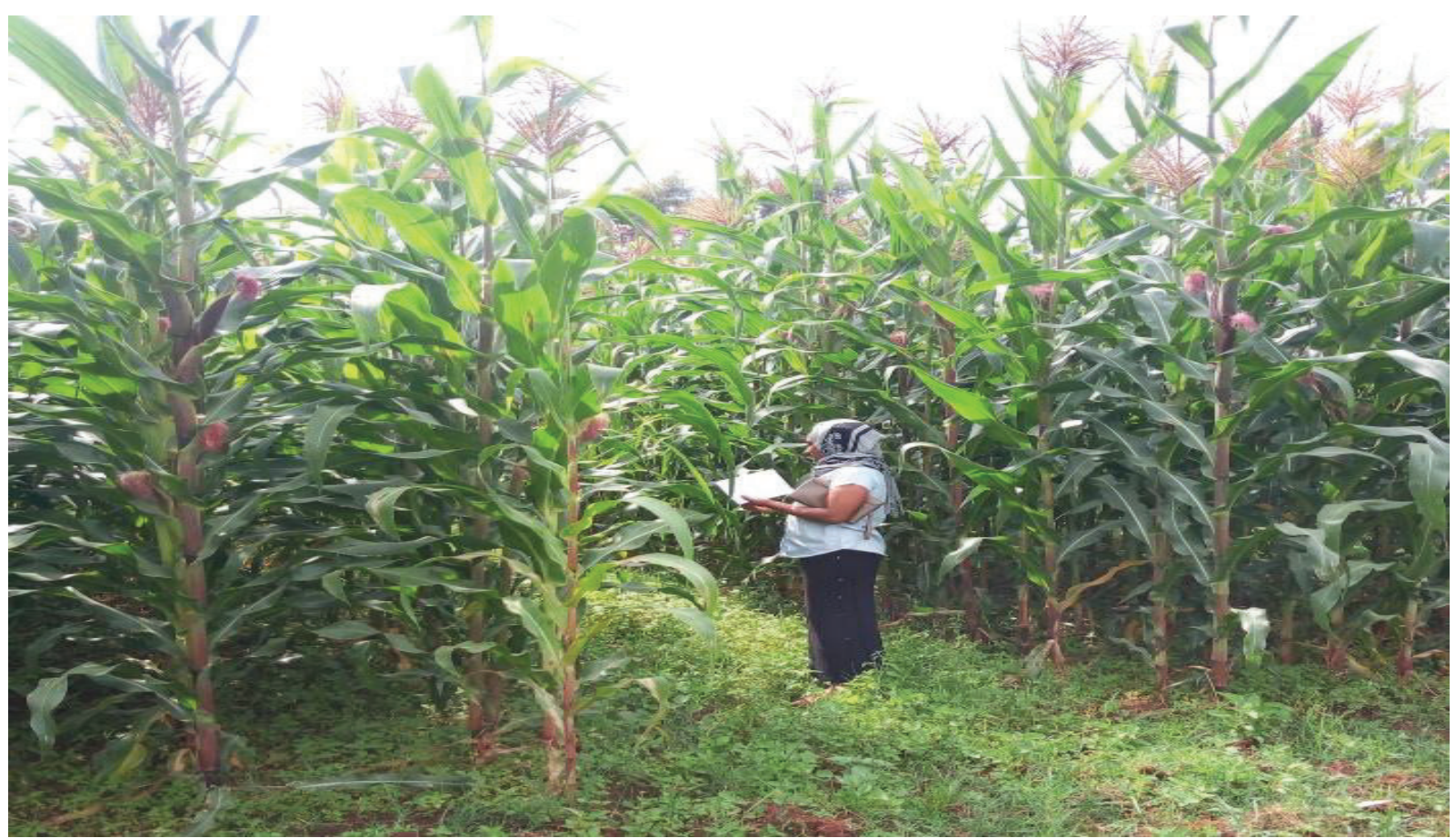

Fig2: Silking and tasseling stage of maize

\subsection{Effect of Nitrogen fertilizer and lime rates on vegetative growth parameters}

As shown in Table 2 plant height of maize was significantly affected by the interaction of the two $(P \leq 0.05)$. The ANOVA indicated that there was a significant increasing in the number of leave per plant by the interaction effect of lime and $\mathrm{N}$ fertilizers $(\mathrm{P} \leq 0.01)$.

\section{Plant height}

In the combined application, the maximum $(352.3 \mathrm{~cm})$ plant height was recorded from plots treated with $0.5 \mathrm{tha}^{-1}$

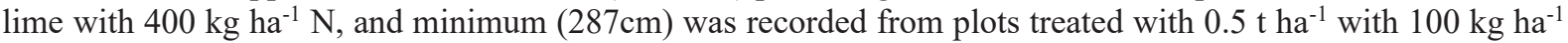
$\mathrm{N}$ (Table 2). This might be a synergetic effect of urea and lime. Increased plant height with the increasing rate of lime and mineral fertilizer rate might be due to the addition of $\mathrm{Ca}^{2+}$ nutrient and reduce $\mathrm{P}$ fixation and, reduce $\mathrm{Al}^{3+}$ and $\mathrm{H}^{+}$ion from the soil, improve CEC, aeration, root penetration, water storage capacity of the soil ([34]. [4] found a significant effect of the combined application of organic and inorganic fertilizers on plant height. Likewise, [22] reported that the integrated application of lime with inorganic fertilizer and compost had a 
significant effect on Barley plant height.

\section{Number of leaves per plant}

As shown in Table 2 the maximum (14.67) NLPP was recorded from plots treated with $0.5 \mathrm{t} \mathrm{ha}^{-1}$ lime and 400 $\mathrm{kg} \mathrm{ha}^{-1} \mathrm{~N}$ while the minimum (11.33) mean NLPP was recorded from plots treated with $0.5 \mathrm{t} \mathrm{ha}^{-1}$ lime and $100 \mathrm{~kg}$ $\mathrm{ha}^{-1} \mathrm{~N}$. This might be added lime and $\mathrm{N}$ in acidic soil improves $\mathrm{N}$ and $\mathrm{P}$ deficiency of the soil which leads to the greenness of maize plant and to be vegetative as well as increase leaf formation. [22] reported higher number of effective tillers of Barley and NPBS due to the synergetic effect of lime, organic and inorganic fertilizers on acidic soils of Wolmera district West Showa.

Table 2. Mean vegetative parameters as influenced by the interaction effect of lime and Nitrogen fertilizer

\begin{tabular}{|c|c|c|c|c|}
\hline Interaction & & & Growth & \\
\hline lime & Nitrogen fertilizer rate & Treatments & $\mathrm{PH}(\mathrm{cm})$ & NLPP \\
\hline \multirow{5}{*}{ L0 } & N0 & $\mathrm{T} 1$ & $251^{\mathrm{g}}$ & 9f \\
\hline & N1 & $\mathrm{T} 2$ & $264.66^{\mathrm{f}}$ & $10.33^{\mathrm{e}}$ \\
\hline & N2 & T3 & $276.33^{\mathrm{e}}$ & $11.33^{\mathrm{d}}$ \\
\hline & N3 & $\mathrm{T} 4$ & $319^{c}$ & $12.33^{\mathrm{c}}$ \\
\hline & N4 & T5 & $346.33^{\text {ba }}$ & $13.33^{\mathrm{b}}$ \\
\hline \multirow[t]{5}{*}{ L1 } & No & T6 & $249^{g}$ & $10^{\mathrm{e}}$ \\
\hline & N1 & $\mathrm{T} 7$ & $287^{\mathrm{e}}$ & $11.33^{\mathrm{d}}$ \\
\hline & N2 & T8 & $304.33^{\mathrm{d}}$ & $13^{\mathrm{b}}$ \\
\hline & N3 & T9 & $337.66^{\mathrm{b}}$ & $14.67^{\mathrm{a}}$ \\
\hline & N4 & $\mathrm{T} 10$ & $352.33^{\mathrm{a}}$ & $14.67^{\mathrm{a}}$ \\
\hline Mean & & & 298.00 & 12 \\
\hline LSD (0.05) & & & 0.109 & 0.58 \\
\hline$S E \pm$ & & & 0.039 & 0.189 \\
\hline $\mathrm{CV}$ & & & 2.14 & 2.823 \\
\hline$p$ & & & $*$ & $* *$ \\
\hline$R$-value & & & 0.983 & 0.9805 \\
\hline
\end{tabular}

$P H=$ plant height, $N L P P=$ number of leaves per plant, $C V=$ Coefficient of Variation, $p=$ probability level; *** $=$ highly significantly different at $p<0.01, *=$ significantly different at $p<0.05$. Means followed by the same letter in a column are not significantly different at $5 \%$ probability level by DMRT

\subsection{Effect of Nitrogen fertilizer and lime rates on yield components}

The interaction of $\mathrm{N}$ fertilizer and lime had a significant effect on the number of cobs, TGW, grain yield of maize, AGDB and $\mathrm{HI}(\mathrm{P} \leq 0.01)$ as shown in Table 3. The interaction of $\mathrm{N}$ fertilizer and lime rate had a significant effect on the number of grains per cobs and STY $(\mathrm{P} \leq 0.05)$.

\section{Number of cobs per plant}

The interaction effect indicated that the maximum (2.93) NCPP was recorded from plots treated with $0.5 \mathrm{tha}^{-1}$ lime and $400 \mathrm{~kg} \mathrm{ha}^{-1} \mathrm{~N}$ while the minimum (1.96) from plots treated with $0.5 \mathrm{t} \mathrm{ha}^{-1}$ lime with $100 \mathrm{~kg} \mathrm{ha}^{-1} \mathrm{~N}$ (Table 3). This might be the result of the synergetic effect of $\mathrm{N}$ and $\mathrm{Ca}$. The improvement of soil conditions through lime and urea fertilizer might be responsible for better cob production. [36] found improved crop yield of Maize after the combined application of lime, manure and mineral fertilizers as compared with the sole application of mineral fertilizers, lime, and manure. However, the result was disagreed with [37] insignificant difference in the number of ears per plant of Maize crop after application of compost with $\mathrm{N}$ fertilizer at Khyber Pakhtunkhwa Agricultural University Peshawar Pakistan.

\section{Number of grains per cob}

As shown in Table 3 the maximum NGPC (518.1) was recorded from plots treated with $0.5 \mathrm{t}^{-1}$ lime and 400 $\mathrm{kg} \mathrm{ha}^{-1} \mathrm{~N}$ while the minimum NGPC (496.5) was recorded from plots treated with $0.5 \mathrm{tha}^{-1}$ lime and $100 \mathrm{~kg} \mathrm{ha}^{-1}$ $\mathrm{N}$. This indicates that treatments with higher $\mathrm{N}$ fertilizer applied with $0.5 \mathrm{t} \mathrm{ha}^{-1}$ lime supported a significantly higher number of grains per cob as compared to the treatments treated with lower fertilizer and lime rates. This high increase in grain number per cob with the increase of $\mathrm{N}$ and lime rate might be due to the synergistic effects of $\mathrm{Ca}$ and $\mathrm{N}$ fertilizers that improved nutrient use efficiencies and normal development of maize. This result is consistent with [22] who reported that, higher numbers of kernels per spike (51) of barley were obtained with integrated application of $611 \mathrm{~kg}$ lime $+5 \mathrm{t}$ compost $+150 \mathrm{~kg} \mathrm{NPSB}+100 \mathrm{~kg} \mathrm{KCl}+72 \mathrm{~kg} \mathrm{~N}^{-1}$ over the control (33). Similarly, [38] reported a significant increase in the number of grains per spike of wheat by applying or manure and mineral fertilizer in combination as compared to inorganic fertilizer alone. 


\section{Thousand grain weight}

Table 3 shows that the maximum TGW of maize $(417.197 \mathrm{~g})$ was obtained from plots treated with $0.5 \mathrm{t} \mathrm{ha}^{-1}$ lime and $400 \mathrm{~kg} \mathrm{ha}^{-1} \mathrm{~N}$ while the lowest TGW (369.57g) was recorded from the control plots compared to the sole application of lime TGW (385.49g). Increased TGW might be due to the synergistic effects of the combined fertilizers for better growth and grain filling of maize. The lowest TGW could be due to shrunken seeds that have small size which contributed to the less grain weight because of nutrient deficiency. [39] reported that increase in TGW due to the synergistic effects of integrated application of lime and inorganic fertilizer that increased growth and grain filling of maize crop in the Angrau, Hyderbad, India. This is in line with [22] that, reported the highest TSW of barley (44g) after the application of lime, compost, NPSB, KCl. Similarly, [4] reported that after the application of $5 \mathrm{tha}^{-1} \mathrm{FYM}$ in combination with $75 \%$ recommended rate of inorganic NP, the highest TGW of barely was obtained compared with application of 100\% recommended rate of inorganic NP. [44] found the highest TGW of wheat grain from the application of $5 \mathrm{t} \mathrm{ha}^{-1} \mathrm{FYM}$ and $50 \%$ inorganic NP, while the lowest TGW was recorded from control.

\section{Grain yield}

Regarding with grain yield the maximum $\left(7,669.88 \mathrm{~kg} \mathrm{ha}^{-1}\right)$ was recorded from plots treated with $0.5 \mathrm{t} \mathrm{ha}^{-1}$ lime with $400 \mathrm{~kg} \mathrm{ha}^{-1} \mathrm{~N}$ while the minimum grain yield $\left(6062.35 \mathrm{~kg} \mathrm{ha}^{-1}\right)$ was recorded from plots treated with $0.5 \mathrm{t}$ $\mathrm{ha}^{-1}$ lime and $100 \mathrm{~kg} \mathrm{ha}^{-1} \mathrm{~N}$ (Table 3). This might be due to improved soil condition as both Ca and $\mathrm{N}$ nutrient was efficiently taken by the plant. This might be due to increased TGW as yield promoting conditions of maize. Since grain yield has strong and positive correlation with lime and nitrogen $(\mathrm{r}=0.999)$. According to [22], Barley grain yield of $2,744 \mathrm{~kg} \mathrm{ha}^{-1}$ that made a significant difference due to the synergistic effect of lime and plant nutrition. Besides, [41] reported significant increase of barley yield over the control after the application of lime and all combinations of fertilizers, either alone or combined.

\section{Above ground biomass}

As shown in Table 3 the maximum $\left(21,302 \mathrm{~kg} \mathrm{ha}^{-1}\right)$ AGDB was recorded from $0.5 \mathrm{t} \mathrm{ha}^{-1}$ lime and $400 \mathrm{~kg} \mathrm{ha}^{-1} \mathrm{~N}$, while the minimum $\left(18,370.8 \mathrm{~kg} \mathrm{ha}^{-1}\right)$ AGDB was recorded from $0.5 \mathrm{t} \mathrm{ha}^{-1}$ lime with $100 \mathrm{~kg} \mathrm{ha}^{-1} \mathrm{~N}$. This enable the maize to respond well to $\mathrm{N}$ fertilizer and lime application as a result of its well-developed root system which facilitates absorbtion of the required nutrients for effective dry matter production by the crop and reduction of exchangeable acidity in the soil. The increased AGDB of maize might be an indicator of grain yield improvement as well as straw yield for animal fodder. The increased AGDB yield might be due to the release of unavailable nutrients from highly acidic soil by liming and $\mathrm{N}$ fertilizers. This high difference in total AGDB could be due to the synergistic effects of $\mathrm{N}$ fertilizer and lime as well as high doses of urea and lime which were well known to increase the vegetative growth of plants, OM, SOC and soil CEC. According to [42, 43, 22] stated that there was significance effect of integrated use of lime and N fertilizer on AGDB of cereals. Likewise, [22] reported that the maximum $\left(11,500 \mathrm{~kg} \mathrm{ha}^{-1}\right)$ biomass data was recorded from plots treated with lime, compost, and NPSB and $\mathrm{N}$ fertilizer than the control $\left(3,433 \mathrm{~kg} \mathrm{ha}^{-1}\right)$. Similarly, [44] reported that total dry matter of maize was higher in treatment combinations of inorganic and organic fertilizers than chemical fertilizers alone. Furthermore, [45] stated that $\mathrm{N}$ availability delayed the vegetative and reproductive stages of phenological development and increase biomass production of maize.

\section{Harvest index}

The maximum (36.33\%) HI was recorded from plots treated with $0.5 \mathrm{t} \mathrm{ha}^{-1}$ lime with $400 \mathrm{~kg} \mathrm{ha}^{-1} \mathrm{~N}$ and the minimum (33\%) was recorded from plots treated with $0.5 \mathrm{t} \mathrm{ha}^{-1}$ lime and $100 \mathrm{~kg} \mathrm{ha}^{-1} \mathrm{~N}$ (Table 3). This could be due to overall improvement of soil conditions by integrated use of lime and N. This indicates that combined use of lime and $\mathrm{N}$ fertilizer improve both grain yield and AGDB. From the total AGDB yield 63.67\% was straw yield. But HI of 33\% revealed that remaining $67 \%$ of total AGDB was straw yield. Similarly, [22] who reported that the HI of barley was significantly $(\mathrm{P} \leq 0.01)$ influenced with integrated application of lime and recommended rate of organic and inorganic fertilizers. Likewise, [22]) found the highest HI of barley (47\%) was obtained with $0.611 \mathrm{t}$ lime ha $\mathrm{h}^{-1}, 5 \mathrm{t}$ compost, $150 \mathrm{~kg} \mathrm{NPSB}, 100 \mathrm{~kg} \mathrm{KCl}$ and $72 \mathrm{~kg} \mathrm{~N} \mathrm{ha} \mathrm{k}^{-1}$ as compared to other treatments that received less combination of applied lime and fertilizers.

\section{Straw yield}

The interaction effect indicate that, the minimum $\left(9,333 \mathrm{~kg} \mathrm{ha}^{-1}\right)$ straw yield was recorded from control plot while the maximum STY was recorded from plots treated with $0.5 \mathrm{t} \mathrm{ha}^{-1}$ lime combined with $300 \mathrm{~kg} \mathrm{ha} \mathrm{H}^{-1} \mathrm{~N}$ $\left(13,224 \mathrm{~kg} \mathrm{ha}^{-1}\right)$ followed by STY $\left(12,984.67 \mathrm{~kg} \mathrm{ha}^{-1}\right)$ obtained from plots treated with the combined use of 0.5 $\mathrm{kg} \mathrm{ha}^{-1}$ lime and $400 \mathrm{~kg} \mathrm{ha}^{-1} \mathrm{~N}$ (Table 3). This might be due to adequate supply of nutrients to the crop helps in the synthesis of carbohydrates, which are required for the formation of protoplasm, thus resulting in higher cell division and cell elongation. Thus, an increase in straw yield might have been on account of overall 
improvement in the vegetative growth of the plant due to the application of lime in combination with $\mathrm{N}$ fertilizer. This is in line with [22] mean straw yield of Barley $\left(6114 \mathrm{~kg} \mathrm{ha}^{-1}\right)$ were obtained with $611 \mathrm{~kg}$ lime ha-1, $5 \mathrm{t}$

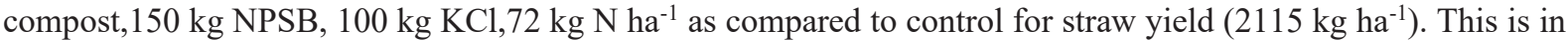
line with [46] integrated application of organic, lime and $\mathrm{N}$ fertilizer is effective for the growth of maize and improving straw yields.

Correlation of Maize yield and yield Components

As shown in Table 4 interaction effect between lime and $\mathrm{N}$ fertilizer showed that grain yield had highly and positively correlated with NGPC $(r=0.966)$ and $\operatorname{NLPP}(r=0.923)$ but highly and negatively correlated with DT ( $\mathrm{r}$ $=-0.957)$ and DS $(r=-0.925)$.

\section{Bivariate Correlation effects of lime and Nitrogen fertilizer on Maize yield and yield components}

Table 4 shows that Straw yield was highly and positively correlated with AGDB(r=0.987) and HI $(\mathrm{r}=0.959), \mathrm{PH}$ $(\mathrm{r}=0.857)$, NLPP $(\mathrm{r}=0.886), \mathrm{DM}(\mathrm{r}=0.915)$, NCPP $(\mathrm{r}=0.841), \mathrm{TGW}(\mathrm{r}=0.743)$ and NGPC $(\mathrm{r}=0.954)$. This indicates that the effect of lime and urea fertilizer showed positive increment. When the rate increased the STY increased as well as all the above parameters also increased. But DS ( $\mathrm{r}=-0.887)$ and DT $(\mathrm{r}=-0.927)$ were highly and negatively correlated with STY (Table 4). This could be due to the effect of lime and urea (i.e when the rate increased the STY increased while DS and DT decreased. Similarly, grain yield was highly and positively correlated with AGDB ( $\mathrm{r}=0.996)$, HI( $\mathrm{r}=0.987)$, STY ( $\mathrm{r}=0.977)$, NGPC $(\mathrm{r}=0.966), \mathrm{DM} \quad(\mathrm{r}=0.931)$, NLPP $(\mathrm{r}=0.0 .923), \mathrm{PH}(\mathrm{r}=0.909), \mathrm{NCPP}(\mathrm{r}=0.885)$ and TGW $(\mathrm{r}=0.797)$, and This indicate that the effect of lime and urea fertilizer (i.e when the rate increased the GY increased as well as all the above parameters also increased. It was also highly and negatively correlated with DT $(r=-0.957)$ and DS $(r=-0.925)$. This indicate that the effect of lime and urea (i.e when lime and urea fertilizer rate increased the grain yield increased while DT and DS decreased (Table 4). This revealed that grain yield was highly significantly increases with an increase of grain yield per cobs, number of cobs per plant and plant height. In general all of the parameters (growth parameters and yield components) were positively and significantly correlated with GY except that of DT and DS. This is supported with [47, 48, 49] grain yield of maize were positively and significantly correlated with yield components.

Table 3. Mean yield components of maize as influenced by the interaction effect of lime and Nitrogen fertilizer.

\begin{tabular}{|c|c|c|c|c|c|c|c|c|c|}
\hline \multicolumn{3}{|c|}{ Interaction effect } & \multirow[b]{2}{*}{ NCPP } & \multirow[b]{2}{*}{ NGPC } & \multirow[b]{2}{*}{ TGW(g) } & \multicolumn{4}{|c|}{ Yield parameters } \\
\hline Lime & $\begin{array}{l}\mathrm{N} \\
\text { fertilizer } \\
\text { rate }\end{array}$ & Treatments & & & & $\begin{array}{l}\text { GY } \quad(k g \\
\left.h^{-1}\right)\end{array}$ & $\begin{array}{l}\text { AGDB } \\
\left(\mathrm{kg} \mathrm{ha}^{-1}\right)\end{array}$ & HI (\%) & $\begin{array}{l}\text { STY } \\
\left(\mathrm{kg} \mathrm{ha}^{-1}\right)\end{array}$ \\
\hline \multirow{5}{*}{ L0 } & N0 & $\mathrm{T} 1$ & $1.00^{\mathrm{f}}$ & $466.33^{\mathrm{i}}$ & $369.577^{f}$ & $3442.47^{j}$ & $12959.2^{\mathrm{h}}$ & $28.33^{\mathrm{f}}$ & $9333^{\mathrm{g}}$ \\
\hline & N1 & $\mathrm{T} 2$ & $1.66^{\mathrm{e}}$ & $495.13^{g}$ & $374.27^{f}$ & $5294.73^{\mathrm{h}}$ & $16904.6^{\mathrm{g}}$ & $31.67^{\mathrm{e}}$ & $11494.7^{\mathrm{e}}$ \\
\hline & $\mathrm{N} 2$ & $\mathrm{~T} 3$ & $1.93^{\mathrm{d}}$ & $506.06^{\mathrm{e}}$ & $380.56^{\mathrm{e}}$ & $5766.53^{\mathrm{g}}$ & $17474.1^{\mathrm{f}}$ & $32.67^{\mathrm{d}}$ & $11708.67^{\mathrm{e}}$ \\
\hline & N3 & $\mathrm{T} 4$ & $2.60^{\mathrm{b}}$ & $509.73^{\mathrm{d}}$ & $386.79^{d}$ & $6116.14^{\mathrm{e}}$ & $18513.5^{\mathrm{e}}$ & $34.33^{\mathrm{c}}$ & $12205.33^{\mathrm{d}}$ \\
\hline & N4 & T5 & $2.8 \mathrm{~b}^{\mathrm{a}}$ & $516.26^{\mathrm{b}}$ & $393.53^{c}$ & $6892.8^{\mathrm{c}}$ & $19693.8^{c}$ & $35^{\mathrm{bc}}$ & $12799.7^{\mathrm{bc}}$ \\
\hline \multirow[t]{5}{*}{ L1 } & N0 & T6 & $1.73^{\mathrm{ed}}$ & $471.13^{\mathrm{h}}$ & $385.49 \mathrm{~d}^{\mathrm{e}}$ & $3758.42^{\mathrm{i}}$ & $13238^{\mathrm{h}}$ & $26.67^{g}$ & $9664^{\mathrm{e}}$ \\
\hline & N1 & $\mathrm{T} 7$ & $1.96^{\mathrm{d}}$ & $496.53^{f}$ & $390.097^{\mathrm{dc}}$ & $6062.35^{f}$ & $18370.8^{\mathrm{e}}$ & $33.0^{\mathrm{d}}$ & $12306^{\mathrm{d}}$ \\
\hline & N2 & $\mathrm{T} 8$ & $2.23^{\mathrm{c}}$ & $509.6^{d}$ & $403.57^{\mathrm{b}}$ & $6516.03^{\mathrm{d}}$ & $19165.1^{d}$ & $34.33^{c}$ & $12645^{c}$ \\
\hline & N3 & T9 & $2.76^{\mathrm{ba}}$ & $513.2^{\mathrm{c}}$ & $415.504^{\mathrm{a}}$ & $7122.44^{b}$ & $20348.1^{b}$ & $35.67^{\text {ba }}$ & $13224^{\mathrm{a}}$ \\
\hline & N4 & $\mathrm{T} 10$ & $2.93^{\mathrm{a}}$ & $518.067^{\mathrm{a}}$ & $417.197^{\mathrm{a}}$ & $7669.88^{a}$ & $21302.4^{\mathrm{a}}$ & $36.33^{\mathrm{a}}$ & $12984.7^{\mathrm{ba}}$ \\
\hline $\begin{array}{l}\text { LSD } \\
(0.05)\end{array}$ & & & 0.2446 & 1.3538 & 5.114 & 49.87 & 493.75 & 0.0092 & 313.17 \\
\hline$S E \pm$ & & & 0.080 & 0.645 & 1.767 & 59.739 & 187.193 & 0.004 & 114.515 \\
\hline $\mathrm{CV}$ & & & 6.59 & 0.157 & 0.761 & 0.495 & 1.617 & 1.628 & 1.542 \\
\hline$p$ & & & $* *$ & $*$ & $* *$ & $* *$ & $* *$ & $* *$ & $*$ \\
\hline $\begin{array}{l}R \text { - } \\
\text { value }\end{array}$ & & & 0.966 & 0.9987 & 0.9778 & 0.9997 & 0.9926 & 0.981 & 0.9878 \\
\hline
\end{tabular}

$N C P P=$ number of cobs per plant, $N G P C=$ number of grains per cob, $A G D B=$ above ground dry biomass, $G Y=$ grain yield, $S T Y=$ Straw yield, $T G W=$ thousand grain weight, $H I=$ harvest index, $L S D=$ Least significance difference, $S E \pm=$ Standard error; $C V=$ Coefficient of Variation, $p=$ probability level; ** significantly different at $p<0.05$. Means followed by the same letters in a column are not significantly different at $p<0.05$. 
Table 4. Pearson's simple correlation coefficient among yield and yield components of maize

\begin{tabular}{|c|c|c|c|c|c|c|c|c|c|c|c|c|}
\hline Correlations & DT & DS & $\mathrm{DM}$ & $\mathrm{PH}$ & NLPP & NCPP & NGPC & TGW & GY & AGDB & $\mathrm{HI}$ & STY \\
\hline DTAS & 1 & & & & & & & & & & & \\
\hline DSILK & $.950^{* *}$ & 1 & & & & & & & & & & \\
\hline $\mathrm{DM}$ & $-.853^{* *}$ & $-.803^{* *}$ & 1 & & & & & & & & & \\
\hline $\mathrm{PH}$ & $-.888^{* *}$ & $-.889^{* *}$ & $.873^{* *}$ & 1 & & & & & & & & \\
\hline NLPP & $-.904^{* *}$ & $-.929^{* *}$ & $.833^{* *}$ & $.925^{* *}$ & 1 & & & & & & & \\
\hline NCPP & $-.936^{* *}$ & $-.901^{* *}$ & $.789^{* *}$ & $.908^{* *}$ & $.890^{* *}$ & 1 & & & & & & \\
\hline NGPC & $-.936^{* *}$ & $-.863^{* *}$ & $.915^{* *}$ & $.871^{\text {** }}$ & $.868^{* *}$ & $.870^{* *}$ & 1 & & & & & \\
\hline TGW & $-.803^{* *}$ & $-.887^{* *}$ & $.658^{* *}$ & $.792^{* *}$ & $.905^{* *}$ & $.794^{* *}$ & $.676^{* *}$ & 1 & & & & \\
\hline GY & $-.957^{* *}$ & $-.925^{* *}$ & $.931^{* *}$ & $.909^{* *}$ & $.923^{* *}$ & $.885^{\text {** }}$ & $.966^{* *}$ & $.797^{* *}$ & 1 & & & \\
\hline AGDB & $-.944^{* *}$ & $-.906^{* *}$ & $.942^{* *}$ & $.897^{* *}$ & $.912^{* *}$ & $.865^{* *}$ & $.962^{* *}$ & $.779^{* *}$ & $.996^{* *}$ & 1 & & \\
\hline $\mathrm{HI}$ & $-.890^{* *}$ & $-.856^{* *}$ & $.961^{* *}$ & $.899^{* *}$ & $.888^{* *}$ & $.821^{* *}$ & $.955^{* *}$ & $.710^{* *}$ & $.987^{* *}$ & $.974^{* *}$ & 1 & \\
\hline STY & $-.927^{* *}$ & $-.887^{* *}$ & $.915^{* *}$ & $.857^{* *}$ & $.886^{* *}$ & $.841^{* *}$ & $.954^{* *}$ & $.743^{* *}$ & $.977^{* *}$ & $.987^{* *}$ & $.959^{* *}$ & 1 \\
\hline
\end{tabular}

$* *=$ Correlation is significant at the 0.01 level (1-tailed).

$H I=$ harvest index, $S T Y=$ straw yield, GYPC $=$ Grain yield per cob, GY=Grain yield, $A G D B=$ above ground dry bi omass, $P H=$ plant height, $N C P P=$ number of cobs per plant, DM= Date of $90 \%$ maturity, DS= Date of $50 \%$ silking and DTAS=Date of $50 \%$ tasseling

\section{Economic feasibility analysis of Maize}

During the 2018/2019 rainy season the market price of Maize taken at Burie District was 10 Ethiopian Birr per kilogram (ETB kg-1). Field prices for NPS, urea, and lime were taken as 10.40, 12.00 and $1.35 \mathrm{ETB}^{\mathrm{kg}} \mathrm{E}^{-1}$, respectively (Table 5). The cost of labour for harvesting and bagging were taken at $28 \mathrm{ETB} 100 \mathrm{~kg}^{-1}$, the cost of labour for incorporation and transportation of lime was taken at $25 \mathrm{ETB} 100 \mathrm{~kg}^{-1}$, the cost of application and transport for fertilizer during planting was $1000 \mathrm{ETB} \mathrm{kg}^{-1}$ considering that 10 laborers can apply fertilizer on a hectare of land in 1 day (daily wage of one laborer is 100 Birr). The same amount of money would be required for side dressing. So it should be 1000 ETB for urea treated plot and daily wage of one labor was $100 \mathrm{ETB}$.

\section{Dominances analysis of maize}

As shown in Table 5 and Table 6 the marginal and dominances analysis of maize in T2, T7, T9 and T8 had greater than 100\% in MRR. The maximum net benefit (58,891.47 Ethiopian Birr) with MRR value of (805.24\%) was obtained from T9-lime $\left.\left(0.5 \mathrm{t} \mathrm{ha}^{-1}\right)+300 \mathrm{~kg} \mathrm{ha}^{-1} \mathrm{~N}\right)$ as compared to T8-lime $\left(0.5 \mathrm{t} \mathrm{ha}^{-1}\right)+\left(200 \mathrm{~kg} \mathrm{ha}^{-1}\right)$ net benefit (47,701.04 ETB) with MRR (203.59\%) (Table 5). This means for T9 on average for each $1 \mathrm{Birr}^{\mathrm{h}} \mathrm{ha}^{-1}$ invested, the return was 1 birr, plus $8.05 \mathrm{Birr} \mathrm{ha}^{-1}$ in the net benefit which is economically feasible as compared

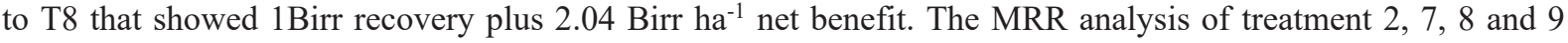
was more than $100 \%$ but T9 is economically feasible to recommend for the farmers. This study suggests that it could be advisable for farmers in the study area to apply integrated lime at $0.5 \mathrm{t} \mathrm{ha}^{-1}$ plus $300 \mathrm{~kg} \mathrm{ha}^{-1}$ nitrogen to enhance maize grain yield and ensuring maximum economic return. This recommendation is also supported by [24] which stated that farmers should be willing to change from one treatment to another if the marginal rate of return of that change is greater than the minimum acceptable rate of return. [22] reported that integrated use of lime, compost, recommended NPS, $\mathrm{KCl}$ and nitrogen fertilizer gave the highest grain yield net benefit and MRR on Barley production. Similarly, [50] reported that higher grain yield and higher net benefit was recorded from higher planting density with higher NPK rate of site specific nutrient management (SSNM).

Table 5. Dominances analysis of Maize

\begin{tabular}{cccc}
\hline Treatments & TVC $\left(\mathrm{ETB} \mathrm{ha}^{-1}\right)$ & Net benefit $\left(\mathrm{ETB} \mathrm{ha}^{-1}\right)$ & Dominance \\
\hline T1 & 5928.92 & 25842.43 & Non-dominated \\
T6 & 6689.272 & 26356.478 & Non-dominated \\
T2 & 8599.701 & 39052.869 & Non-dominated \\
T7 & 9598.291 & 44962.859 & Non-dominated \\
T3 & 9899.129 & 41999.641 & Dominated \\
T8 & 10943.23 & 47701.04 & Non-dominated \\
T4 & 11281.57 & 43763.69 & Dominated \\
T9 & 12332.93 & 58891.47 & Non-dominated \\
T5 & 12630.82 & 51769.03 & Dominated \\
T10 & 13667.99 & 55360.93 & Dominated \\
\hline
\end{tabular}

Treatment $3=$ with $200 \mathrm{~kg} \mathrm{ha}^{-1} \mathrm{~N}$ alone, T4=with $300 \mathrm{~kg} \mathrm{ha}^{-1} \mathrm{~N}$ alone and T5= with $400 \mathrm{~kg} \mathrm{ha}^{-1} \mathrm{~N}$, treatment $10=$ with $0.5 \mathrm{t} \mathrm{ha}^{-1}$ lime and $400 \mathrm{~kg} \mathrm{ha}^{-1} \mathrm{~N}$ were dominated treatments. Hence, these are rejected from further consideration in marginal analysis. Based on this treatment 3, 4, 5 and 10 are rejected because they are dominated by other treatments. 
Table 6. Marginal analysis of Maize

\begin{tabular}{|c|c|c|c|c|c|c|}
\hline Treatments & $\begin{array}{c}\text { Grain Yield (kg } \\
\left.\text { ha }^{-1}\right)\end{array}$ & $\begin{array}{c}\text { Adjusted yield } \\
(-10 \%)(\mathrm{kg} \\
\left.\mathrm{ha}^{-1}\right) \\
\end{array}$ & $\begin{array}{c}\text { Gross } \\
\text { return } \\
\left(\mathrm{ETB} \mathrm{ha}^{-1}\right) \\
\end{array}$ & $\begin{array}{c}\text { TVC } \\
\left(\begin{array}{c}\text { ETB ha } \\
\text { 1) }\end{array}\right. \\
\end{array}$ & $\begin{array}{c}\text { Net benefit (ETB } \\
\text { ha }^{-1} \text { ) }\end{array}$ & $\begin{array}{c}\text { MRR } \\
(\%)\end{array}$ \\
\hline T1 & 3530.15 & 3177.135 & 31771.35 & 5928.92 & 25842.43 & ---- \\
\hline T6 & 3671.75 & 3304.575 & 33045.75 & 6689.272 & 26356.478 & 67.6 \\
\hline $\mathrm{T} 2$ & 5294.73 & 4765.257 & 47652.57 & 8599.701 & 39052.869 & 664.5 \\
\hline $\mathrm{T} 7$ & 6062.35 & 5456.115 & 54561.15 & 9598.291 & 44962.859 & 591.8 \\
\hline $\mathrm{T} 3$ & 5766.53 & 5189.877 & 51898.77 & 9899.129 & 41999.7 D & ---- \\
\hline $\mathrm{T} 8$ & 6516.03 & 5864.427 & 58644.27 & 10943.23 & 47701.04 & 203.59 \\
\hline $\mathrm{T} 4$ & 6116.14 & 5504.526 & 55045.26 & 11281.57 & 43763.69 D & ---- \\
\hline T9 & 7122.44 & 6410.196 & 64101.96 & 12332.93 & 58891.47 & 805.24 \\
\hline $\mathrm{T} 5$ & 6892.8 & 6203.52 & 62035.2 & 12630.82 & 51769.03 D & ----- \\
\hline $\mathrm{T} 10$ & 7669.88 & 6902.892 & 69028.92 & 13667.99 & 55360.93D & ---- \\
\hline
\end{tabular}

$D=$ dominated treatment

\section{Agronomic use efficiency}

Agronomic use efficiency reflects the direct production impact of an applied fertilizer and relates directly to economic return. The interaction between lime and $\mathrm{N}$ fertilizer significantly affected agronomic use efficiency as $\mathrm{N}$ fertilizer rate increased but lime rate is constant (Table 7). The highest agronomic use efficiency was obtained from combined use of $400 \mathrm{~kg} \mathrm{ha}^{-1} \mathrm{~N}$ fertilizer with $0.5 \mathrm{t} \mathrm{ha}^{-1}$ lime than $100 \mathrm{~kg} \mathrm{ha}^{-1} \mathrm{~N}$ with $0.5 \mathrm{t} \mathrm{ha}^{-1}$ lime.

As shown in Table 7 the nutrient use efficiency (NUE) was good for those plots treated with $100 \mathrm{~kg} \mathrm{ha}^{-1} \mathrm{~N}$ and has the highest NUE which is $5.88 \%$. This might be due to the fact $\mathrm{N}$ fertilizers were known in releasing nutrients immediately to the soil and crop which account in yield increase. The maximum (5.88\%) AUE was recorded from plots treated with $100 \mathrm{~kg} \mathrm{ha}^{-1} \mathrm{~N}$ while the lowest AUE $(0.202 \%)$ was recorded from plots treated with $0.5 \mathrm{t} \mathrm{ha}^{-1}$ lime alone. This confirms that, inorganic fertilizer release nutrients immediately while lime does not release nutrients immediately for maize. The remaining might be lost through erosion, leaching and changed to organic stock. The result was similar with [48] who reported that, the highest agronomic use efficiency $(16.14 \%)$ of maize was obtained from plots treated with mineral fertilizer only $\left(75 \mathrm{~kg} \mathrm{ha}^{-1} \mathrm{~N}\right.$ fertilizer plus 100 $\mathrm{kg} \mathrm{ha}^{-1}$ NPSZnB fertilizer and lowest NUE $(0.04 \%)$ was obtained from plots treated with compost only $(5000 \mathrm{~kg}$ $\left.\mathrm{ha}^{-1}\right)$. Similarly, [51] reported that low nitrogen use efficiency in cereal production due to dinitrifecation. Plots treated with lime alone or in combination with urea fertilizer were low in their NUE. This is due to the fact that lime is not providing nutrients to the soil and crops immediately. Similarly, [52] found the effect of $\mathrm{N}$ fertilizer rate on agronomic use efficiency.

Table 7. Agronomic use efficiency for maize

\begin{tabular}{lcccccc}
\hline Treatments & lime(kg/ha) & $\begin{array}{c}\text { N fertilizer } \\
\left(\mathrm{kg} \mathrm{ha}^{-1}\right)\end{array}$ & $\begin{array}{c}\text { NPS } \\
\text { fertilizer } \\
\left(\mathrm{kg} \mathrm{ha}^{-1}\right)\end{array}$ & $\begin{array}{c}\text { Total nutrient } \\
\text { added }\end{array}$ & $\begin{array}{c}\text { Grain yield (kg } \\
\left.\text { ha }^{-1}\right)\end{array}$ & AUE \\
\hline L0N0 & -- & -- & 200 & 200 & 3530.15 & -- \\
L0N1 & -- & 100 & 200 & 300 & 5294.73 & $\mathbf{5 . 8 8}$ \\
L0N2 & -- & 200 & 200 & 400 & 5766.53 & 5.59 \\
L0N3 & -- & 300 & 200 & 500 & 6116.14 & 5.17 \\
L0N4 & -- & 400 & 200 & 600 & 6892.8 & 5.604 \\
L1N0 & 500 & -- & 200 & 700 & 3671.75 & $\mathbf{0 . 2 0 2}$ \\
L1N1 & 500 & 100 & 200 & 800 & 6062.35 & 3.16 \\
L1N2 & 500 & 200 & 200 & 900 & 6516.03 & 3.32 \\
L1N3 & 500 & 300 & 200 & 1000 & 7122.44 & 3.59 \\
L1N4 & 500 & 400 & 200 & 1100 & 7669.88 & 3.76 \\
\hline
\end{tabular}

\section{Conclusions}

Application of lime and $\mathrm{N}$ fertilizer reduced the tassling and silking period. Grain yield of maize was positively and significantly correlated with yield components. The maximum net benefit $(58,891.5$ ETB) and MRR (805.24\%) was obtained from combined use of $0.5 \mathrm{t} \mathrm{ha}^{-1}$ lime with $300 \mathrm{~kg} \mathrm{ha}^{-1} \mathrm{~N}$ fertilizer. Integrated application of lime and $\mathrm{N}$ fertilizer increased agronomic use efficiency of maize. Based on the result of this study we conclude that, the optimum rate of lime and $\mathrm{N}$ fertilizer for yield increment, soil fertility improvement and maximum economic benefit was combined application of $0.5 \mathrm{t} \mathrm{ha}^{-1}$ lime and $300 \mathrm{~kg} \mathrm{ha} \mathrm{g}^{-1} \mathrm{~N}$ with full recommendation of NPS. It is recommended to the farmers in the study area. The government should supply lime $\left(\mathrm{CaCO}_{3}\right)$ and $\mathrm{N}$ fertilizer to the farmers, further study should be done in the residual effect of lime for 
further growing seasons, with organic and inorganic fertilizers as well as economic feasibility.

Acknowledgement; this work has been conducted at Burie Polytechnic College farm site. We thanked top managerial body of the college. We also thanked Department of Natural Resources Management, Bahir Dar University College of Agriculture and Environmental Sciences.

Declaration of interest statement; the authors declare that they have no conflict of interest.

Data availability statement: The data that support the findings of this study are openly available as the corresponding author's request.

\section{References}

[1] Hilaire, L. Corn: An American Native. Spanning the Gap The newsletter of Delaware Water Gap National Recreation Area Vol. 22 No. 1 Spring 2000. U.S. Dept. of the Interior National Park Service, 2000.

[2] Zamir M.S.I, Yasin G, Javeed H.M.R, Ahmad A.U.H, Tanveer A, Yaseen M. Effect of different sowing techniques and mulches on the growth and yield behavior of spring planted maize (Zea mays L.). Cercetari Agronomice in Moldova, 1(153): 77-82, 2013.

[3] Geremewu Taye. Effect of Nitrogen and Phosphorus Fertilizers on the Growth, Yield and Yield Components of Maize (Zea mays L) at Nejo Western Wollega, Ethiopia, 2009.

[4] Mitiku Woldesenbet, and Asnakech Haileyesus. "Effect of nitrogen fertilizer on growth, yield and yield components of maize (zea mays 1.) in Decha district, Southwestern Ethiopia" International Journal of Research Granthaalayah, Vol. 4, No. 2: 95-100, 2016.

[5] MoARD (Ministry of Agriculture and Rural Development). Animal and plant health regulatory: Directorate crop variety registers. Addis Ababa, Ethiopia. pp: 36-51, 2009.

[6] Wende Abera. 2013. Genetic Diversity, Stability, and Combining Ability of maize Genotypes for Grain Yield and Resistance to NCLB in the Mid-Altitude Sub-Humid Agro-Ecologies of Ethiopia, PhD dissertation, African Center for Crop Improvement School of Agricultural, Earth and Environmental Sciences College of Agriculture, Engineering and Science University of KwaZulu-Natal Republic of South Africa, 2013.

[7] Tsedeke Abate, Bekele Shiferaw, Abebe Menkere, Dadne Wagary, Yilma Kebede, Kendie Tesfay, Tolera Keno. Factors that transformed maize productivity in Ethiopia. Food security,7(5),965-981, 2015.

[8] Mosisa Worku, Hadji Tuna,Mandefro Nigussie,Abera Deressa,Tanner D.,and Twumasi-Afriyie S. Maize roduction trends and research in Ethiopia. Mandefro,N Tanner, DG, Twumasi-Afriyie S.(eds), 10-14, 2002.

[9] Berhanu Gebremedhin, Fernandez-Rivera S., Mohammed Hassena, Mwangi W. and Seid Ahmed. Maize and livestock: Their inter-linked roles in meeting human needs in Ethiopia. Research Report 6.ILRI (International Livestock Research Institute), Nairobi, Kenya, 2007.

[10] Central Statics Agency (CSA). Report on large and medium scale manufacturing and electricity Industry Survey,Centeral Statistical Agency, Ethiopia, 2011.

[11] Gardner, F.P., R.B. Pearce and R.L. Mitchell. Physiology of crop plants. Ames: Iowa State University, 327p, 1985.

[12] Devi, I.S. and Muhammad S. Character association and path co-efficient analysis of grain yield and yield components in double crosses of maize. Crop Research. 21: 355 359, 2001.

[13] Taylor and Francis. Soil Sampling and Methods of Analysis $2^{\text {nd }}$ ed, vol. 1, Canadian Society of Soil Science, Canada, 2006.

[14] Mohammadi GH, Kahrizi D, MF Sadeghi. Maize, Academic Press of Islamic Azad University of Kermanshah, p 619, 2008.

[15] Kena Kelbesa. Effect of nitrogen rates and inter row spacing on growth, yield and yield components of maize (Zea mays 1.) at Nejo, Western Ethiopia, 2015.

[16] Jiban S. Effect of nitrogen and plant population on flowering and grain yield of winter maize. Sky Journal of Agricultural Research, 2(5):64 -68, 2013.

[17] Singh, S., Verma S. C. and Singh R. P. Effect of integrated nutrient management on yield, nutrient uptake andchanges in soil fertility under rice (Oryza sativa)- lentil (Lens culinaris) cropping system, Indian J.of Agron.,36: 191-197, 2001.

[18] International Food Policy Research Institute (IFPRI). Fertilizer and soil fertility potential in Ethiopia: constraints and opportunities for enhancing the system working paper, pp 26-53, 2010.

[19] Wende Abera. Genetic Diversity, Stability, and Combining Ability of maize Genotypes for Grain Yield and Resistance to NCLB in the Mid-Altitude Sub-Humid Agro-Ecologies of Ethiopia, PhD dissertation, African Center for Crop Improvement School of Agricultural, Earth and Environmental Sciences College of Agriculture, Engineering and Science University of KwaZulu-Natal Republic of South Africa, 2013.

[20] Mosisa Worku, Twumasi-Afriyie S.,Wolde Legesse,Tadesse Berhanu,Demisie Girma, Bogale Gezahegn,Prasanna BM. Meeting the challenges of global climate change and food security through innovative maize research .Proceedings of the National Maize Workshop of Ethiopia, 3; Addis Abeba, Ethiopia;18-20April,2011:CIMMYT, 2012. 
[21] Kebede Dinkecha and Dereje Tsegaye. Effects of Liming on Physicochemical Properties and Nutrient Availability of Acidic Soils in Welmera Woreda, Central Highlands of Ethiopia. Biochemistry and Molecular Biology. Vol. 2, No.6, pp.102 109.doi: 10.11648/j. mb.20170206.16, 2017.

[22] Woubshet Demissie, Selamyihun Kidanu, Tolera Abera and Cherukuri V Raghavaiah. Effects of Lime, Blended Fertilizer (NPSB) and Compost on Yield and Yield Attributes of Barley (Hordium Vulgare L.) on Acid Soils of Wolmera District, West Showa, and Ethiopia. Ethiop.J.Appl.Sci. Technol. Vol.8 (2): 84-100, 2017.

[23] Esayas Eyasu, Dereje Shanka, Dawit Dalga and Eyasu Elias. Yield Response of Maize (Zea mays L.) Varieties to Row Spacing Under Irrigation at Geleko, Ofa Woreda, Wolaita Zone, Southern Ethiopia, 20(1): 1-10, 2018; Article no.JEAI.37096 ISSN: 2457-0591, 2018.

[24] CIMMYT. From agronomic data to farmer recommendation. An economic training manual. Completely revised edition. D.F. Mexico. Pp. 9-12, 1988.

[25] Craswell, E.T. and Godwin, D.C 1984. In: Mangel, K.andKirkby, E.A. Principles of Plant Nutrition. Panima publishing panima publishing Coperation. New Delhi, India, 1996.

[26] Negash Teshome. Influence of potassium fertilization and liming on growth, grain yield, and quality of soybean (Glycine max 1.(merrill) on acidic soil in Gobu sayo district, western Ethiopia, Msc thesis, Jimma University, 2018.

[27] Begizew Golla. Effect of Nitrogen Rate and Intra-Row Spacing on Yield and Yield Components of Maize (Zea mays L.) at Bako, Western Ethiopia. M.Sc. thesis Jimma University Ethiopia, 2018.

[28] Shrestha, J. 2013. Effect of nitrogen and plant population on flowering and grain yield of winter maize. Sky $J$ Agric Res, 2(5), pp.64-68.

[29] Jassal, R.K., Kang, J.S., Singh, H. and Singh, T. Growth, Phenology and Seed Yield of Fodder Maize in Relation to Different Planting Methods and Nitrogen Levels. Int. J. Curr. Microbiol. App. Sci, 6(4), pp.1723-1735, 2017.

[30] Imran, S., Arif, M., Khan, A., Khan, M.A., Shah, W. and Latif, A. Effect of nitrogen levels and plant population on yield and yield components of maize. Advances in Crop Science and Technology, pp.1-7, 2015.

[31] Kumar, D., Kumar, M., \& Kumar, R. Evaluate the integrated nutrient use on growth and yield of hybrid maize under central plain zone of Uttar Pradesh, India. International Journal of Current Microbiology Applied Science, 7(3), 518-530. doi:10.20546/ ijcmas.2018.703.062, 2018.

[32] Amanullah Khalid, S. Phenology, growth and biomass yield response of maize (Zea mays L.) to integrated use of animal manures and phosphorus application with and without phosphate solubilizing bacteria. Journal of Microbial and Biochemical Technology, 7, 439-444, 2015.

[33] Brady N.C.and Weil R.R. The nature and properties of soils, $13^{\text {th }}$ Ed, Prentice HallInc., NewJersey,USA.960p, 360p, 2002.

[34] Rahman M., Begum M. F., Alam M. Effect of bio compost, cow dung compost and NPK fertilizers on growth, yield and yield components of chilli, International Journal of Biosciences (IJB) Bangladesh, 2012.

[35] Abdissa Bekele, Kibebew Kibret, Bobe Bedadi, Tesfaye Balemi and Markku Yli-Halla. Effects of lime, vermicompost and chemical P fertilizer on yield of maize in Ebantu district, Western highlands of Ethiopia, Vol.13 (10), pp.477-489, doi: 10.5897/AJAR2017.12949, 2018.

[36] Kimiti WinnieWanjiru. Lime, Manure and Inorganic Fertilizer Effects on Soil Chemical Properties, Maize Yield and Profitability in Tharaka-Nithi County, Kenya.MSc thesis Environmental Science in the School of Environmental Studies of Kenyatta University, 2018.

[37] Ali, S., Uddin, S., Ullah, O., Shah, S., Ali, S. U. D. T., \& Ud Din, I. Yield and yield components of maize response to compost and fertilizer nitrogen, https://www.iiste.org/Journals/index.php/FSQM/article/view/21360, 2012.

[38] Arif, M, Ali, S, Khan, A, Jan, T and Akbar, M. Influence of farm yard manure application on various wheat cultivars. Sarhad J. of Agric.22 (1):27-29, 2006.

[39] Anuradha L. Integrated nutrient management in groundnut (Arachis hypogaea L.) M.Sc. thesis. Angrau, Hyderabad, 2003.

[40] Saidu, A, Ole, K and Leye, BO. Performance of Wheat (Triticum aestivum L.) as influenced by complementary use of organic and inorganic fertilizers. Intern. J. of Sci. and Nature 5(4): 532-537, 2012.

[41] Shiferaw Bokore and Anteneh Fikadu. Lime and NPK Effect on Soil Acidity and Yield of Barely in different Acid Soils of Southern Region, Ethiopia. Intern. J. of Natu. Sci. Res. 2(7): 113-122, 2014.

[42] Woldeyesus Sinebo, Gretzmacher, R and Edelbauer, A. Genotypic variation for nitrogen use efficiency in Ethiopian barley, Field Crop Res. 85: 43-60, 2004.

[43] Getachew Agegnehu, Angaw Tsigie and Agajie Tesfaye. 2012. Evaluation of Crop Residue Retention, Compost and Inorganic Fertilizer Application on barley productivity and Soil Chemical properties in the Central Ethiopia. 
[44] Kibunja Catherine, Francis B Mwaura, Daniel Mugendi. Long-term land management effects on soil properties and microbial populations in a maize-bean rotation at Kabete, Kenya, Article in African journal of agricultural research, t: https://www.researchgate.net/publication/228503225, 2010.

[45] Fageria V, Moreira A. \& Coelho A. M. Yield and yield components of upland rice as influenced by nitrogen sources, 361-370, 2011.

[46] Makinde Eyitayo and Olukemi Ayoola. Growth, Yield and NPK Uptake by Maize with Complementary Organic and Inorganic Fertilizers, African Journal of Food Agriculture Nutrition and Development 10(3), Doi: 10.4314/ajfand.v10i3.54078, 2010.

[47] Yihenew G.Selassie. The effect of $\mathrm{N}$ fertilizer rates on agronomic parameters, yield components and yields of maize grown on Alfisols of Northwestern Ethiopia. Environ Syst Res (2015) 4:21, Doi:10.1186/s40068015-0048-8, 2015.

[48] Habtamu Admas, Heluf Gebrekidan, Bobe Bedadi and Enyew Adgo. Effects of Organic and Inorganic Fertilizers on Yield and Yield Components of Maize at Wujiraba Watershed, North-western Highlands of Ethiopia, American Journal of Plant Nutrition and Fertilization Technology, 5: 1-15, 2015.

[49] Tesfaye Bayu. Effect of Integrated Fertility Management on Soil Physico-Chemical Properties and Yield and Yield Components of Maize (Zea Mays L.) and Tef (Eragrostis Tef) at Yilmana Desnsa District, Northwestern Ethiopia, MSc thesis, Bahir Dar University, 2017.

[50] Trinh, Q.K., Pham, S. T., and Christian, W. Improving of maize yield and profitability through site specific nutrient management (SSNM) and planting density, International Plant Nutrition Institute, Southeast Asia Program, Singapore 16: 88-92, 2008.

[51] William R. Raun and Gordon V. Johnson. Improving Nitrogen Use Efficiency for Cereal Production. Oklahoma State University, Stillwater, OK 74078, 1999.

[52] William F, Jean bonhtel, and Tom Fiesinger. Compost sampling for nutrient quality parameters: variability of sampler, timing and pile depth. New York State Energy Research and Development Authority, Albany, New York, 2012.

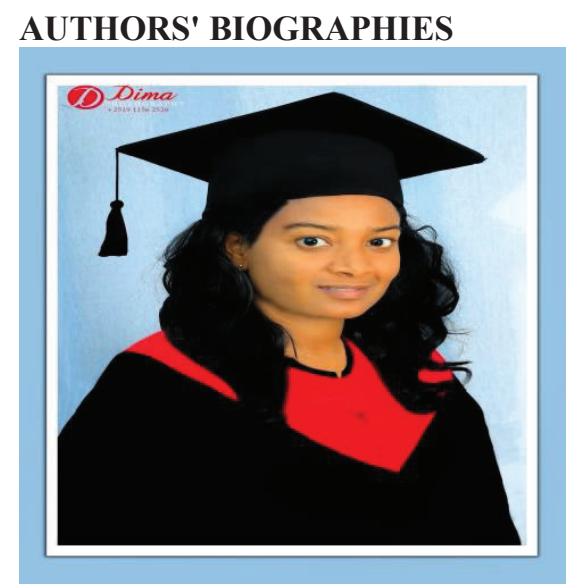

Mrs. Birtukan Amare kebede, Bsc in Natural Resource Management (2010) from Debre Markos University Ethiopia, M.Sc, in Watershed and Soil Conservation (2020) from Bahir Dar University Ethiopia, a Trainer more than 6 years in Natural Resource Management department of Plant Science and Natural Resources Management in Burie Polytechnic College, Ethiopia 